Article

\title{
Sorption Membranes and Filter for Water Purification and Disinfection in Outdoor Conditions
}

\author{
Igor Zhuravlev
}

Institute for Sorption and Problems of Endoecology NAS of Ukraine, Gen. Naumov str., 13, 03164 Kiev, Ukraine; igorzhuravlev1@gmail.com

Received: 27 December 2018; Accepted: 4 March 2019; Published: 11 March 2019

check for

updates

\begin{abstract}
The aim of this article was to develop a simple, cheap, light, highly efficient sorption membrane and filtering device for the purification of naturally polluted water with application in outdoor conditions. Sorption membranes have been prepared from cellulose pulp using paper and pulp technology. The sorbents were introduced into paper pulp as a filler (as activated carbon) or were chemically grafted to cellulose fibers. The absorption ability of such membranes assembled in a filter device has been investigated. The removal of weighted small mechanical particles, microorganisms, dissolved organic contaminants and colloids, and the undesirable ion impurities by the filter was investigated. Using a $10 \times 10 \mathrm{~cm}$ filter, purification and disinfection of 18 liters of natural polluted water from a lake was done. Purification of dirty water occurs with gravity from a tank (bucket).
\end{abstract}

Keywords: membranes; disposable filter; sorbents; sorption of microorganisms; purification; decontamination; outdoor conditions; drinking water; paper-pulp technology

\section{Introduction}

Purification of naturally polluted water from natural reservoirs, such as rivers, lakes, swamps, and puddles, in the absence of centralized water supply systems is a very urgent task. For these purposes, there are many large stationary or portable systems for water purification in large volumes [1]. Such water purification systems are based on the use of various purification methods, are manufactured in series, and are capable of ensuring low cost of treated water; however, they are, overall, still relatively expensive [2]. When it is necessary to clean small volumes of water in the field-a few liters or tens of liters-and the filter should be compact, easy to use, efficient, and cheap, problems can arise.

It should be noted that there are many compact devices for water purification in the field [3]. Such devices that are designed for repeated use have some disadvantages. As a rule, antimicrobial cleaning with such filters is solved by pumping contaminated water through a 0.2 micron-hole nano-membrane using a portable pump (included in the filter equipment). The most compact and cheapest devices, such as a tube-straw, allow a person to drink decontaminated water from any puddle by sucking the water through the tube. The main types of compact water purifiers are (1) pump filters and purifiers, (2) gravity filters, (3) ultraviolet light purifiers, (4) bottle filters, (5) squeeze filters, and (6) straw-style filters. An analysis of the market has shown that such straw tubes cost at least 20 US dollars after a discount [4]. But to pay $\$ 20$ for $10 \mathrm{~L}$ of drinking water even in the field is expensive. Moreover, such straw tubes provide only antimicrobial protection since they contain only a nano-membrane. In many cases, natural water must also be cleaned from odorous and dissolved toxic organic impurities. The problem of purification from the ions of heavy metals and radionuclides is also not solved. There are also reagent methods of water treatment, for example, coagulants and flocculants or disinfecting by chlorine-containing tablets [4,5]. Such treatment of water with reagents is cheaper, but it is more complicated than simple filtration and does not always provide the necessary quality of water purification. 
It is obvious that in many cases-for example, for tourists traveling in nature, military expeditions and hikes, and people working far from civilization-simple, cheap, efficient, and compact filters for high-quality cleaning of small quantities of polluted natural waters are need. Such filters may be intended for single use. Naturally polluted water may contain different types of impurities. Biological pollution includes bacteria, viruses, spores, pollen, parasites, etc. There may be relatively large mechanical particles in the water-clay, mineral particles, soil, and the remains of living organisms. Various organic substances and undesirable ionic impurities, for example, heavy metal ions and radionuclides, can be present in dissolved form in dirty water. The task of creating filters for complex purification of polluted natural waters can be solved by creating a filter containing several specialized membrane-elements, which are assembled in a bag, fastened, and sealed around the perimeter of the bag. Each membrane purifies contaminated water from a specific type of contamination. Four filled membranes are proposed, which will comprehensively purify water successively, one by one. Three of the four membranes are made with pulp and paper technology where the active sorbent is among the cellulose fibers as filler or fixed on the surface of the cellulose fibers. The first membrane in the course of the water cleans it from relatively large mechanical particles. This is the so-called deep membrane because the deposition of particles occurs throughout the entire volume of the membrane. The second membrane contains a sorbent that binds microbiological contaminations. The third membrane contains activated carbon and absorbs dissolved organic matter. The fourth membrane contains an ion exchanger, which absorbs unwanted ionic impurities.

\section{Materials and Methods}

\subsection{Reagents}

All chemical reagents used were of Sigma-Aldrich analytical grade. For the adsorption experiments, chloride and nitrate salts were dissolved in distilled water. "Endo Medium" was from Ukrchimexpo Ltd. (Kiev, Ukraine). The strains of microorganisms used were Pseudomonas aeruginosa and Escherichia coli and were from D.K. Zabolotny Institute of Microbiology and Virology NAS of Ukraine (Kiev, Ukraine). For analysis, double-distilled deionized water was used.

\subsection{Adsorption Experiments}

The adsorption of heavy metal cations was conducted at room conditions to determine their respective adsorption capacity. The static adsorption studies were processed with the method of separate constant weights of the sorbent (crushed cellulose-hydroxyapatite membrane). The weight ratio of the sorbent to the sorption solution was 1:250 (0.2 $\mathrm{g}$ of sorbent, 50 milliliters of solution). The contact time of the sorbent with the solution was $48 \mathrm{~h}$ at constant stirring. After reaching equilibrium, sorbents were filtered from equilibrium solutions. Equilibrium solutions were analyzed for metal content by atomic absorption spectroscopy. The magnitude of the absorption of metals (uptake) was calculated by Formula (1):

$$
A=\frac{(\text { Cinit. }- \text { Cequil. } .) V}{1000 m}
$$

where $A$ is the metal cation uptake $(\mathrm{mg} / \mathrm{g})$; Cinit. and Cequil. are the initial and equilibrium concentrations of the metal cations $(\mathrm{mg} / \mathrm{L})$, respectively; $V$ is the volume of the solution for sorption $(\mathrm{mL}) ; m$ is the mass of the sorbent $(\mathrm{g})$.

Dynamic studies were conducted by passing contaminated water through a filter at a certain rate. The filtrates were collected and analyzed for suspended solids, turbidity, chromaticity, hardness, organic matter content, etc., using known methods [6]. Microbiological studies were carried out for Pseudomonas aeruginosa and Escherichia coli microorganisms using known methods [7]. One milliliter of each filtrate was added to 10 milliliters of nutrient broth obtained from the preparation "Endo 
Medium" in Petri dishes. After keeping the Petri dishes at $36^{\circ} \mathrm{C}$, the number of colonies formed was counted visually under a magnifying glass.

\subsection{Analytic Methods}

The specific surface area, pore volume, and sample pore volume distribution by effective radii were performed via nitrogen sorption-desorption measurements using Gemini-02 "Micromeritics" (Micromeritics Instruments Corporation, Norcross, GA, USA) porosimeter [8,9]. The outgas temperature was $160{ }^{\circ} \mathrm{C}$. XRD studies were performed using DRON-3 (Bourevestnik, Inc., St. Petersburg, Russia) Cu K $\alpha$ XRD spectrometer. $\mathrm{pH}$ measurements were conducted using a И-160-M (Gomel Plant of Measuring Equipment, Gomel, Belarus) $\mathrm{pH}$ meter. Electron and optical microscopy were performed using a JEOL JSM-840A (JEOL, Ltd., Tokyo, Japan) electron microscope and an OLYMPUS (Olympus Corporation, Tokyo, Japan) optical microscope. The atomic absorption spectrometer used was an AA 6300 SHIMADZU (Shimadzu Corporation, Tokyo, Japan) [10].

\subsection{Preparation of Sorption Membranes}

Sorption membranes were manufactured using pulp and paper technology [11-15]. Pure pulp in the form of dry fibers or paper was pulped in water in a high-speed blender. To the obtained pulp, a powder of activated carbon or other filler-sorbent was added and the resulting mixture was again mixed to homogenize. The resulting pulp was poured into a Büchner funnel on a Bunsen flask. The vacuum was created in the Bunsen flask with a vacuum pump, and, as a result, excess water was removed from the pulp. The resulting casting was removed from the funnel, leveled, and dried in an air oven at a temperature of $110^{\circ} \mathrm{C}$. After drying, ready-made sorption membranes were obtained, which were cut to the required shape and size. In membranes of this type, the active sorbent was in the form of filler and was weakly bound to the cellulose fibers. In the case of bactericidal and ion-exchange membranes, the active sorbent was grafted or fixed on the surface of the cellulose fibers. In general, the technology of production was similar to the above. The difference is that the introduction and fixing of the active sorbent on the cellulose fibers was a multistage process. In the synthesis of a bactericidal membrane based on the copper form of carboxymethylcellulose (CMC), in the first stage of the synthesis, the cellulose fiber in the form of pulp was treated with a solution of the sodium form of carboxymethylcellulose. At the second stage, a solution of copper salt was introduced, for example, copper sulfate, which fixed the copper form of $\mathrm{CMC}$ on the cellulose fibers. Next was the washing and drying at $110{ }^{\circ} \mathrm{C}$. The synthesis of ion-exchange membranes consisted of the sequential introduction of reagents into the cellulose pulp to precipitate hydroxyapatite on the cellulose fibers.

\section{Results and Discussion}

\subsection{Rough Mechanical Filtration Membrane}

In order to filter out rough mechanical particles with a size of a few microns and above, dense cotton tissue was used. This tissue should have a large bulk surface so that the precipitated particles are distributed not only on the surface but also in the depth of the tissue. Due to this, the filtration rate will decrease slightly even with a large quantity of precipitated particles $[13,16]$. For the experiments, a tissue of $600 \mathrm{~g}$ per square meter density was used.

\subsection{Bactericidal Membranes}

Two types of bactericidal membranes were manufactured and investigated. The first was the copper form of carboxymethylcellulose [17] grafted on cellulose fibers with activated carbon as filler (Figure 1A). The second was a composite membrane consisting of cellulose fibers, chrysotile fibers and containing aluminum hydroxide particles as filler (Figure 1B). 


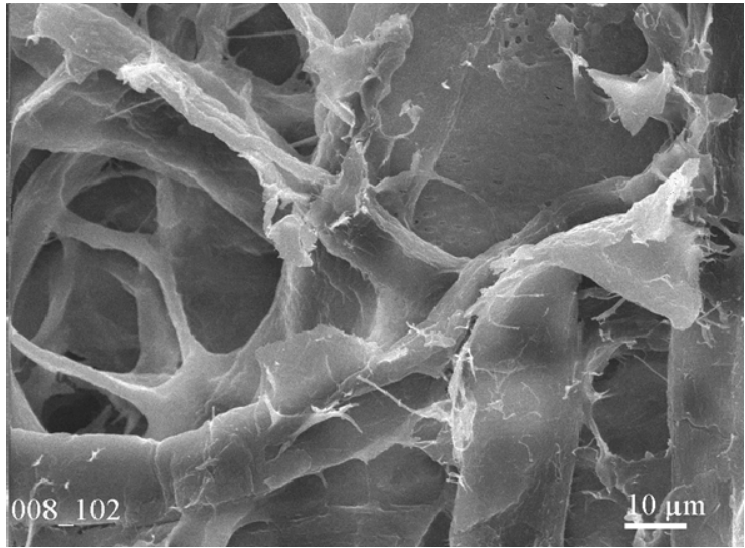

(A)

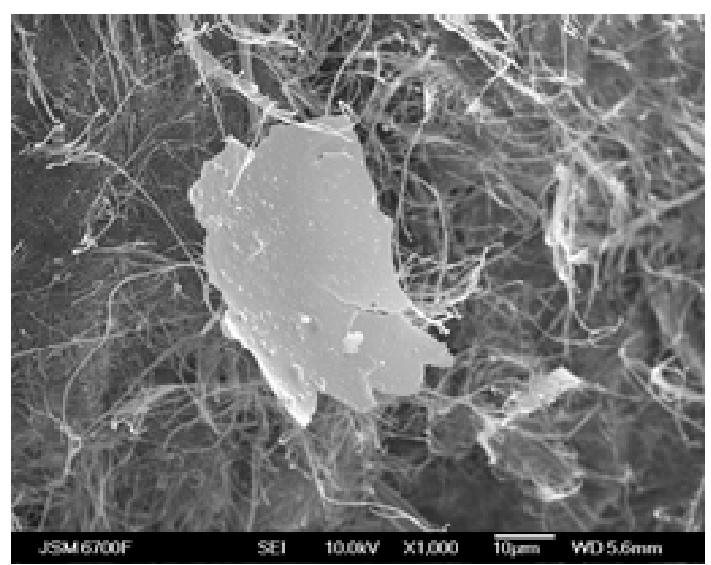

(B)

Figure 1. SEM images: $\mathrm{Cu}$-carboxymethylcellulose grafted on cellulose fibers with activated carbon (A), $\mathrm{Al}(\mathrm{OH})_{3}$ particles among chrysotile fibers $(\mathbf{B})$. The marks on the SEM images $(\mathbf{A}, \mathbf{B})$ are 10 micrometers.

Figure 2 shows the pore volume distribution functions of the effective radius for both studied bactericidal membranes. As can be seen from the electronic photographs, the $\mathrm{Cu}-\mathrm{CMC}$ polymer enveloped not only cellulose fibers but also particles of activated carbon, forming characteristic rounded transitions between the elements of the structure. For the membrane containing the copper form of CMC and activated carbon (A), it is clearly visible that the porous structure of this membrane coincides with the coal-cellulose (will be shown later). Since the cellulose fibers and the copper form of CMC are almost non-porous, it can be concluded that the copper form of CMC does not block the porosity of the activated carbon and does not enter the pores of the carbon. This is an important and valuable property of this composition since in this case, in addition to its bactericidal properties, it is able to absorb the dissolved organic substances by activated carbon. In general, as can be seen from Figure 2, the porosity of the $\mathrm{Cu}-\mathrm{CMC}$ form is microporous. The form of cellulose-chrysotile-aluminum hydroxide (B) is also microporous due to the microporosity of the chrysotile fibers. The meso- and macroporous components are seen on the porogram due to the porosity between the chrysotile fibers whose diameter is part of a micron. It is necessary to explain the apparent lack of porosity in the cellulose fibers and the copper form of CMC. The microfibrils of the cellulose fibers are interconnected with lignin. The structure of the copper form of CMC still requires additional study. It can be said that in the wet state, it is highly hydrated and permeable to ions and small molecules. Before the porometric study, the sample was dried at a temperature of $140-160{ }^{\circ} \mathrm{C}$. After this temperature treatment, the microfibril-binding lignin and the copper form of $\mathrm{CMC}$ were dehydrated and compressed, losing their permeability. Its porosity disappears after such treatment.

Studies on the adsorption of microorganisms on bactericidal membranes were carried out from artificially prepared solutions-imitants. We investigated purifying water from Pseudomonas aeruginosa and Escherichia coli. The results of the study are presented in Table 1. One liter of the imitant solution was passed through each of the investigated membranes. The filtration time of $1 \mathrm{~L}$ of water through the bactericidal membranes was 10-12 min (filtration surface was $200 \mathrm{~cm}^{2}$ ). Samples $\mathrm{Cu}-\mathrm{CMC} 1-3$ contained copper in the amounts of $100 \%, 150 \%$, and $200 \%$, respectively, of the number of active CMC groups. In this case, an additional amount of copper precipitation took place due to hydrolysis and complexation with CMC. Samples CCHA1-3 also contained the active component-chrysotile fibers with aluminum hydroxide-in the amounts of $100 \%, 150 \%$, and $200 \%$ of cellulose fibers. It is seen that with an increase in the content of the active component, the efficiency of purification from microorganisms for both types of sorbents increased. In order to evaluate the cleaning ability, membranes with a copper form of CMC were studied for two types of microorganisms. It must be said that such a high content of Pseudomonas aeruginosa in ordinary polluted natural waters is not observed. Such content of Pseudomonas aeruginosa may be only in sewage. The investigated initial concentration 
of Escherichia coli is quite real for polluted natural waters, and both types of studied sorbents could efficiently extract it from the water. The question touching water purification from microorganisms and disinfection requires additional research [17-20]. Did microorganisms die while in solution or did adsorption on the surface occur? Apparently, electrostatic adsorption on the surface takes place for both types of sorbents. In the case of the copper form of CMC, microbes on the surface of the sorbent die from copper poisoning. In the case of the chrysotile hydroxide aluminum-cellulose sorbent, microbes on its surface die due to immobilization and disruption of vital functional processes.

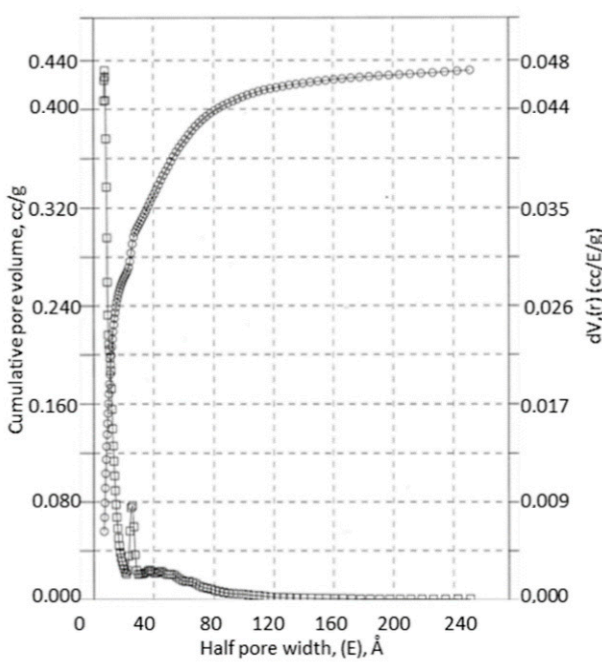

(A)

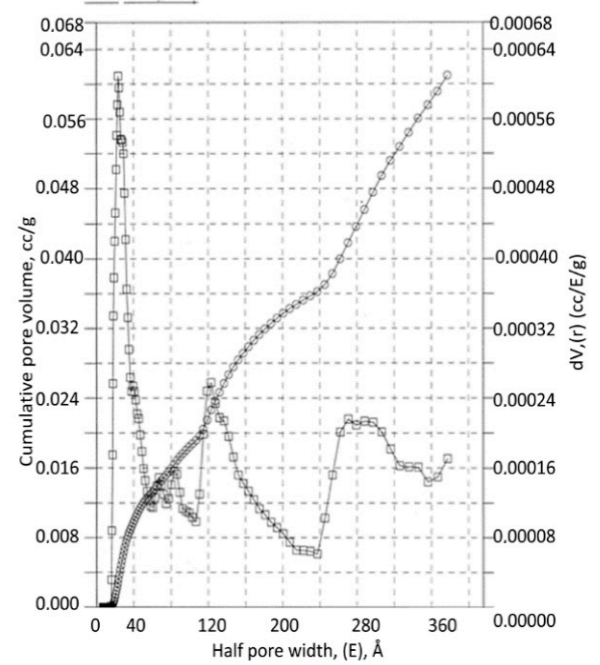

(B)

Figure 2. The functions of pore volume distribution on the effective radius for both bactericidal membranes studied. Cu-carboxymethylcellulose grafted on cellulose fibers with activated carbon ZL-302 (A), cellulose-chrysotile fibers-Al(OH) $)_{3}\left(\mathrm{Ssp} .=14 \mathrm{~m}^{2} / \mathrm{g} ; \mathrm{Vs}=0.12 \mathrm{~cm}^{3} / \mathrm{g}\right)(\mathbf{B}), \bigcirc-\mathrm{V}, \square-\mathrm{dV}$.

Table 1. Water purification from microorganism using bactericidal membranes: $\mathrm{Cu}$-carboxymethylcellulose grafted on cellulose fibers with activated carbon ( $\mathrm{Cu}-\mathrm{CMC} 1-3)$, and $\mathrm{Al}(\mathrm{OH})_{3}$-chrysotile fibers-cellulose (CCHA 1-3); $\mathrm{CFU} / \mathrm{mL}$-bacteria concentration in colony forming units in solution.

\begin{tabular}{ccccc}
\hline \multirow{2}{*}{ Membrane Sample } & \multicolumn{4}{c}{ Bacteria Content, CFU/mL } \\
\cline { 2 - 5 } & Initial & Filtrate & Initial & Filtrate \\
\cline { 2 - 5 } & 2300 & 24 & 35 & 13 \\
Cu-CMC-1 & 2300 & 10 & 35 & 0 \\
Cu-CMC-2 & 2300 & 4 & 35 & 0 \\
Cu-CMC-3 & - & - & 35 & 3 \\
CCHA-1 & - & - & 35 & 1 \\
CCHA-2 & - & - & 35 & 0 \\
CCHA-3 & & & & \\
\hline
\end{tabular}

\subsection{Carbon-Cellulose Membranes}

Naturally polluted waters usually contain various dissolved organic matter. To remove such pollutants from the water, highly porous activated carbon has been invented. Such carbons are usually derived from various natural products. Thermolysis of various plant products leads to their decomposition with the formation of a cake or non-porous carbon. During the subsequent purging of water vapor or air (activation) through such heated coal, pores are formed and carbon is partially burned out. A highly porous activated carbon is created, which absorbs organic substances dissolved in water well. Depending on the feedstock, coal of different porosities can be constructed. If wood is 
carbonized, then after activation, wide-porous carbon is made with good sorption kinetics but little selectivity to dissolved organic matter. If, for example, walnut shells, coconuts, fruit stones, etc. are used, microporous coal with high selectivity and capacity for organic substances and a large specific surface is formed. Such coal is often called biochar. For water filters, activated carbon is often used in the form of a free layer of pieces of different or a specific size. In many cases, this provides the necessary parameters for the cleaning process and the desired result [21]. However, if the thickness of the carbon layer is small, and the carbon itself is unconsolidated, it is possible that the carbon layer is washed out by the flow of water, the mass of carbon is shifted to the side, it clumps, or other process defects occur. If, on pulp and paper technology, the composite is prepared from pieces of carbon evenly distributed between cellulose fibers, then when purifying water using filters made in this way, it will be possible to avoid all those disadvantages. It is for these reasons that cellulose-carbon composite membranes were made to purify water from dissolved organic substances. Microporous carbon derived from coconut shells ZL-302 was used for the pulp and carbon membranes. Figure 3 presents an SEM photograph of such a pulp and carbon membrane. The image clearly shows the ribbon fibers of cellulose with sticky pieces of activated carbon. Figure 4 represents the function of pore volume distribution on the effective radius of ZL-302 activated carbon.

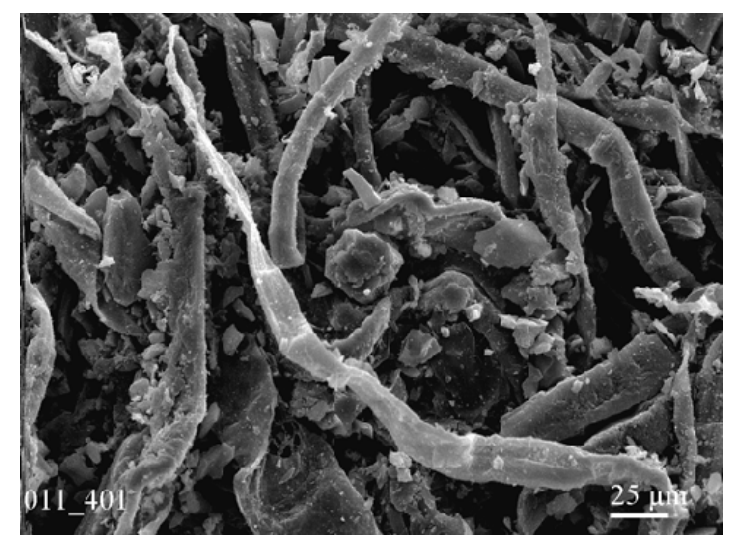

Figure 3. SEM image of a cellulose-carbon membrane.

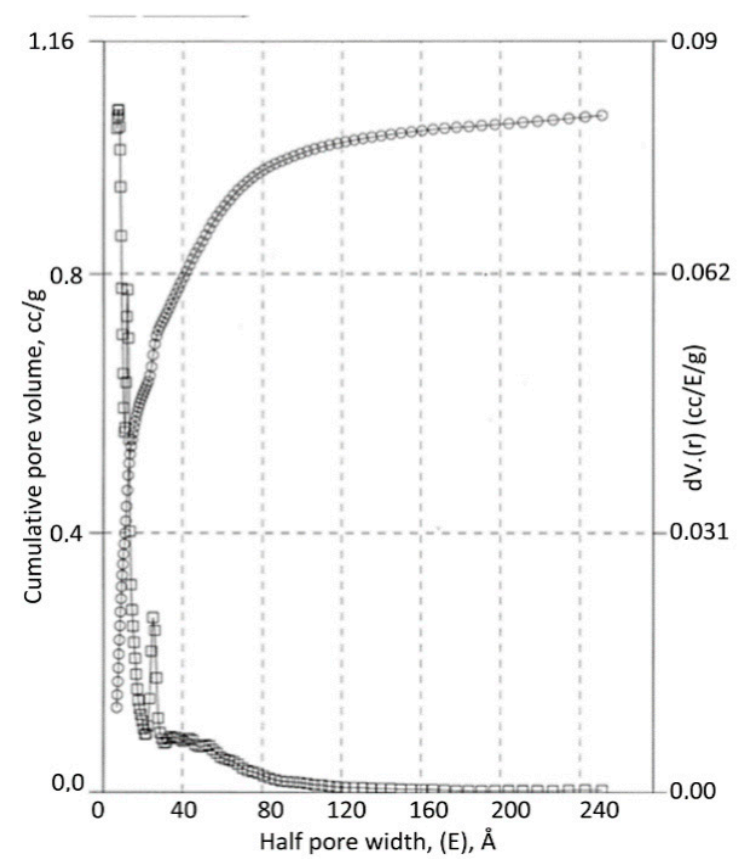

Figure 4. The function of pore volume distribution on the effective radius of ZL-302 activated carbon (Ssp. = $1618 \mathrm{~m}^{2} / \mathrm{g} ; \mathrm{Vs}=1.13 \mathrm{~cm}^{3} / \mathrm{g}$ ), $\bigcirc-\mathrm{V}, \square-\mathrm{dV}$. 
Fulvic acids and humic acids from soil give color and taste to natural water and are the main sources of pollution from dissolved organic substances. The unit of measurement of chromaticity is a relative value-grades, which is measured photometrically. The total content of organic substances in water is determined by its oxidizability by potassium permanganate and is expressed by the relative value "chemical oxygen consumption." Table 2 presents the results of purification of polluted natural water from dissolved organic substances based on the results of the analysis of the color and oxidation of the source water and filtrates. Studies were carried out according to the results of cleaning $1 \mathrm{~L}$ of polluted water with filters that contained different amounts of cellulosic-carbon membranes. Each of such membranes was $3.5 \mathrm{~mm}$ thick.

Table 2. The results of purification of natural polluted water from dissolved organic substances. The initial water chromaticity was 22 grads; initial water oxidizability was $4.2 \mathrm{mgO}_{2} / \mathrm{L}$; each such membrane used was $3.5 \mathrm{~mm}$ thick. The filtration time of $1 \mathrm{~L}$ of water through cellulose-carbon membranes was less than 10 min (filtration surface was $200 \mathrm{~cm}^{2}$ ).

\begin{tabular}{cccc}
\hline № & Amount of Membrane & Chromaticity, grad & Oxidizability, $\mathbf{m g O}_{\mathbf{2}} / \mathbf{L}$ \\
\hline 1 & 1 & 7.6 & 2.7 \\
2 & 2 & 7.3 & 2.0 \\
3 & 3 & 6.8 & 1.1 \\
4 & 4 & 6.4 & 0.8 \\
\hline
\end{tabular}

\subsection{Apatite-Cellulose Membranes}

Purifying polluted water from unwanted ionic impurities is important in some cases. Many ion exchange materials have been developed to extract metal ions from water. This applies primarily to heavy metals and radionuclides [22-25]. Special attention was paid to hydroxyapatite $\mathrm{Ca}_{10}\left(\mathrm{PO}_{4}\right)_{6}(\mathrm{OH})_{2} \cdot \mathrm{xH}_{2} \mathrm{O}$-a cheap and highly effective ion-exchanger in neutral media [26,27]. However, it is a powder material that is difficult to use in dynamic flow-through water purification devices. If hydroxyapatite is precipitated on cellulose fibers, then a flow-through, highly efficient cleaning device can be obtained. By successive impregnation of cellulose fibers with reagents, it was possible to precipitate hydroxyapatite in the form of fine crystals fixed on the fibers. Figure 5 shows the SEM image of hydroxyapatite precipitated on cellulose fibers. In this picture, particles - crystals of apatite - fixed on the surface of the fibers and germinated deep into the fibers are clearly visible. Figure 6 shows the function of pore volume distribution on the effective radius for a cellulose-hydroxyapatite composite membrane. A significant mesoporous component corresponds to intercrystallite porosity. The XRD of this sample, shown below in Figure 7, confirms the formation of hydroxyapatite. Sorption of cations from natural water by the sorbent (crushed cellulose-hydroxyapatite membrane) was carried out under static conditions at a constant ratio of the volume of the solution to the mass of the sorbent with constant stirring. The calculation of the adsorption isotherms was carried out as follows. After reaching the sorption equilibrium of the sorbent with the metal solution, the equilibrium solutions were filtered out. The concentration of the metal in the equilibrium filtrate was determined by atomic absorption spectroscopy. Then, the amount of metal absorbed by $1 \mathrm{~g}$ of the sorbent was calculated. As a result, a sorption isotherm was constructed-the dependence of the amount of absorbed metal as a function of the metal concentration in the corresponding equilibrium solution. Figure 8 shows the isotherms of the ion-exchange adsorption of cadmium and copper ions from polluted natural water. Sorption from natural water was hampered by the competitive influence of hardness salts, hydrolysis, and complex formation. From the calculated isotherms, the apatite-cellulose membranes could effectively remove cadmium from such water. Copper sorption capacity is somewhat lower but still quite high. 


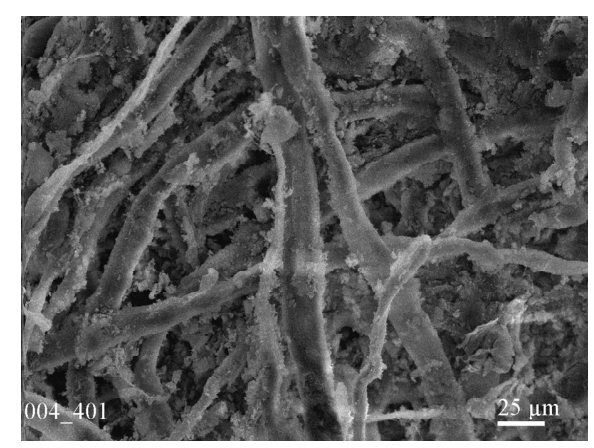

Figure 5. SEM image of the cellulose-hydroxyapatite membrane.

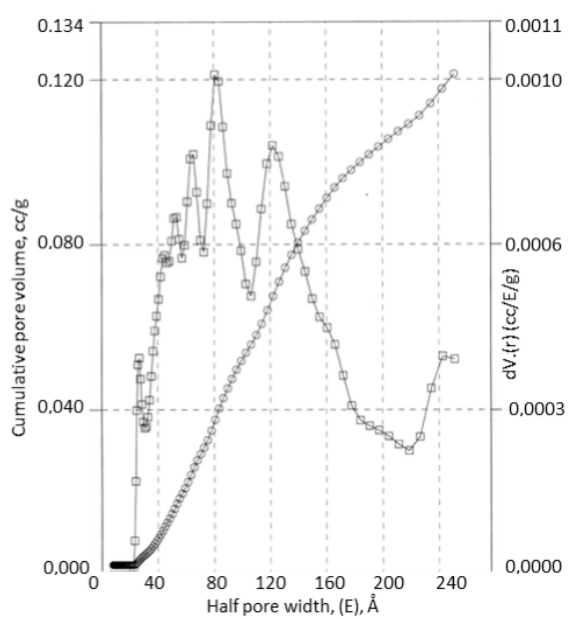

Figure 6. The function of pore volume distribution on the effective radius for the cellulose-hydroxyapatite composite membrane (Ssp. $=32 \mathrm{~m}^{2} / \mathrm{g} ; \mathrm{Vs}=0.16 \mathrm{~cm}^{3} / \mathrm{g}$ ), $\bigcirc \mathrm{V}, \square-\mathrm{dV}$.

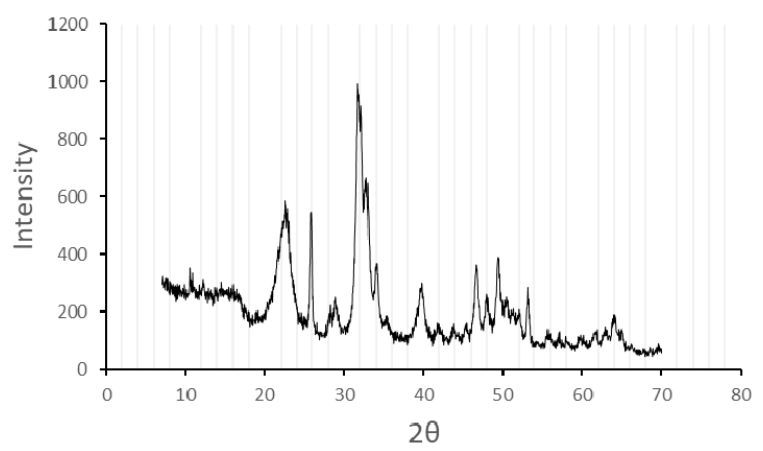

Figure 7. XRD of the cellulose-hydroxyapatite composite membrane $(\mathrm{Cu} \mathrm{K} \alpha)$.

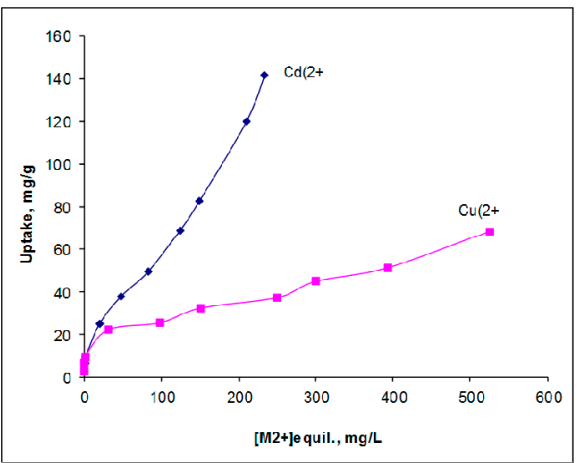

Figure 8. Isotherms of ion-exchange adsorption of cadmium and copper ions from polluted natural water $S: L=1: 250$; contact time $48 \mathrm{~h}$ at constant stirring. 


\subsection{Membrane Filter and Contaminated Water Purification}

Complex purification of polluted natural water is possible on a filter containing all four types of membranes (black, white, green, brown) and dividing plastic grids (green) folded in a bag (Figure 9A). The membrane package was sealed around the perimeter. The sealing of the membrane package was carried out with a gluing gun. In this gun, the polymer glue rod was melted; the melt was squeezed onto the end of the membrane package. The hardened glue sealed the membranes and stiffened the entire filter (Figure 9B). The filter contains two identical sets of membranes located on both sides of the filter (Figure 9A) so that the purified water, after it passes through both packages, falls into the middle part of the filter. Purified water flows out of the middle part of the filter into the container through a plastic tube. Figure 9 shows the membrane package and the already assembled filter ready for operation.

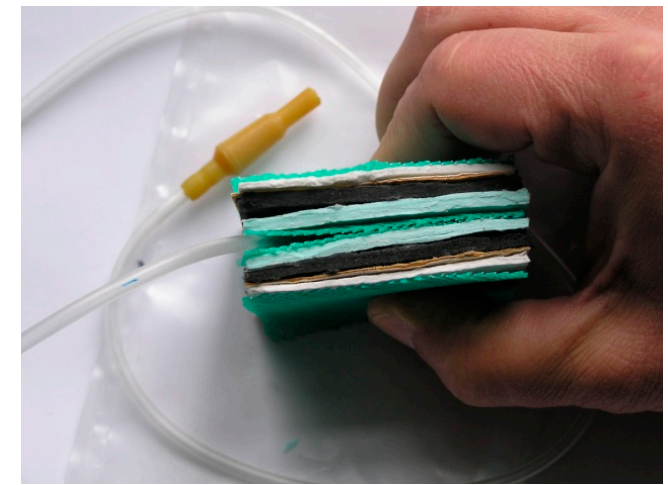

(A)

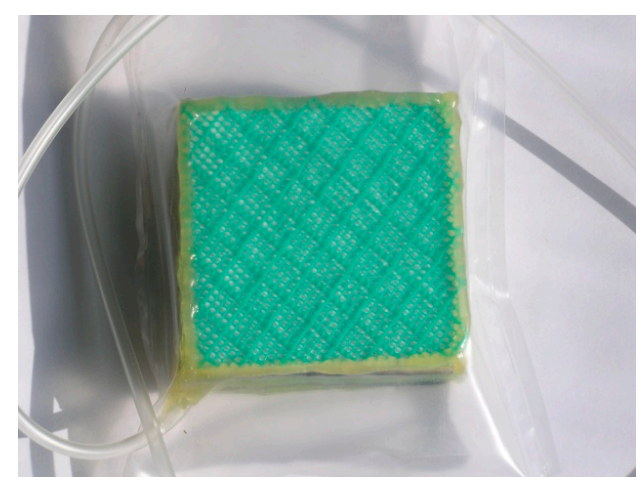

(B)

Figure 9. Membrane package (A) and the assembled filter ready for operation (B).

Purification and disinfection of water on the filter is provided in that way. Contaminated water is poured into a bucket, which is placed on a hill. In this bucket with polluted water, a filter with a plastic tube is placed. Water infiltrates the filter and is cleaned. The cleaned filtrate then flows through the plastic tube into the receiving container, which is located below. To start filtering, water must be sucked into the tube with a syringe or by mouth, after which filtration takes place on its own due to the difference in levels. Contaminated water in the bucket is periodically poured. Using such a double-sided filter with a size of $10 \times 10 \mathrm{~cm}$, it was possible to clean $18 \mathrm{~L}$ of polluted natural water from the city lake to the level of drinking water in accordance with the sanitary standards of Ukraine.

Table 3 presents the results of the analyzes of the main indicators of contaminated water, water purified using a filter, and sanitary requirements for drinking water in Ukraine. The water filtration rate through this filter was $1 \mathrm{~L}$ in 10-12 min. A total of $18 \mathrm{~L}$ of contaminated water was filtered through the filter and the second time the filter was not used. The possibility of multiplex purifications using one filter requires additional research. 
Table 3. Results of water analyzes before and after filtering through a $10 \times 10 \mathrm{~cm}$ filter.

\begin{tabular}{|c|c|c|c|c|c|c|c|c|c|c|}
\hline \multirow[b]{2}{*}{ Water } & \multicolumn{9}{|c|}{ Physicochemical Properties of Water Quality } & \multirow{2}{*}{$\begin{array}{l}\text { Escherichia Coli, } \\
\text { Group Microbia } \\
\text { Content CFU/L }\end{array}$} \\
\hline & $\mathrm{pH}$ & $\begin{array}{l}\text { Chromaticity, } \\
\text { grad }\end{array}$ & $\begin{array}{l}\text { Turbidity, } \\
\text { mg/L }\end{array}$ & $\begin{array}{c}\text { Total } \\
\text { Hardness, } \\
\text { mgeqv/L }\end{array}$ & $\begin{array}{c}\text { Iron Total, } \\
\text { mg/L }\end{array}$ & $\begin{array}{l}\text { Manganese, } \\
\mathrm{mg} / \mathrm{L}\end{array}$ & $\begin{array}{l}\text { Nitrates, } \\
\text { mg/L }\end{array}$ & $\begin{array}{l}\text { Oxidizability, } \\
\mathrm{mgO}_{2} / \mathrm{L}\end{array}$ & $\begin{array}{l}\text { Dry residue, } \\
\mathrm{mg} / \mathrm{L}\end{array}$ & \\
\hline $\begin{array}{l}\text { Requirements for } \\
\text { drinking water }\end{array}$ & $6.5-8.5$ & $\leq 20$ & $\leq 0,58$ & $\leq 7$ & $\leq 0.2$ & $\leq 0.05$ & $\leq 50$ & $\leq 5$ & $\leq 1000$ & $<3$ \\
\hline Initial water & 7.9 & 22.5 & 3.43 & 6.58 & 0.24 & 0.1 & 2.1 & 4.2 & 551 & 1250 \\
\hline 2nd filtered liter & 6.5 & 7.5 & $<0.1$ & 5.26 & 0.1 & 0.015 & 2.7 & 2.6 & 504 & $<3$ (norm) \\
\hline 6th filtered liter & 7.68 & 6.8 & $<0.1$ & 6.3 & 0.01 & 0.031 & 1.9 & 1.0 & 536 & $<3$ \\
\hline 10th filtered liter & 7.86 & 6.8 & $<0.1$ & 6.44 & $<0.1$ & 0.037 & 1.8 & 1.0 & 546 & $<3$ \\
\hline 14th filtered liter & 7.92 & 6.8 & $<0.1$ & 6.46 & $<0.1$ & 0.024 & 2.2 & 0.9 & 547 & $<3$ \\
\hline 18th filtered liter & 7.96 & 6.8 & $<0.1$ & 6.58 & $<0.1$ & 0.018 & 2.1 & 0.9 & 548 & $<3$ \\
\hline
\end{tabular}




\section{Conclusions}

This article describes cellulose-based sorption membranes manufactured with pulp and paper technology. Four types of membranes for purifying naturally polluted water from large mechanical particles, bacteriological contamination, dissolved organic substances, and undesirable ionic impurities were investigated and reported during the purification of polluted water. A high cleaning efficiency of the polluted water on such membranes has been determined. Using a $10 \times 10 \mathrm{~cm}$ consisting of a set of such membrane filters, and sequential filtration of polluted water, it was possible to clean and disinfect $18 \mathrm{~L}$ of naturally polluted water from a lake to the quality level of drinking water.

Funding: This research received no external funding.

Conflicts of Interest: The author declare no conflict of interest.

\section{References}

1. Figoli, A.; Criscuoli, A. (Eds.) Sustainable Membrane Technology for Water and Wastewater Treatment; Springer Nature, Singapore Pte Ltd.: Singapore, 2017; p. 387. ISBN 978-981-10-5623-9. (eBook).

2. Basile, A.; Cassano, A.; Rastogi, N. (Eds.) Advances in Membrane Technologies for Water Treatment; Elsevier: Amsterdam, The Netherlands, 2015; p. 667. ISBN 978-1-78242-126-9. (online).

3. Tansel, B. New Technologies for Water and Wastewater Treatment: A Survey of Recent Patents. Recent Pat. Chem. Eng. 2008, 1, 17-26. [CrossRef]

4. How to Choose a Water Filter or Purifier. Available online: https://www.rei.com/learn/expert-advice/ water-treatment-backcountry.html (accessed on 5 March 2019).

5. Monaghan, S.; Inspector (Project Manager), EPA. Water Treatment Manual: Disinfection; Environmental Protection Agency an Ghníomhaireacht um Chaomhnú Comhshaoil: Wexford, Ireland, 2011; p. 200. ISBN 978-184095-421-0.

6. Rice, E.; Baird, R.; Eaton, A. (Eds.) Standard Methods for the Examination of Water and Wastewater, 23rd ed.; American Public Health Association: Washington, DC, USA, 2017; p. 277. ISBN 9780875532875.

7. Glymph, T. Wastewater Microbiology: A Handbook for Operators; American Water Work Association: Washington, DC, USA, 2005; p. 182. ISBN 9781583213438.

8. Gregg, S.J.; Sing, K.S.W. Adsorption, Surface Area and Porosity, 2nd ed.; Academic Press Inc.: San Diego, CA, USA, 1982; p. 313. ISBN 0-12-300956-1.

9. Conner, W.C.; Cevallos-Candau, J.F.; Weist, E.L. Characterization of Pore Structure: Porosimetry and Sorption. Langmuir 1986, 2, 151-154. [CrossRef]

10. Kellner, R.; Mermet, J.M.; Otto, M.; Widmer, H.M. (Eds.) Analytical Chemistry; Wiley-VCH: Weinheim, Germany, 1998; p. 942. ISBN 3-527-2881-3.

11. Monica, E. (Ed.) Pulp and Paper Chemistry and Technology; Walter de Gruyter GmbH \& Co. KG.: Berlin, Germany, 2009; Volume 1, p. 420. ISBN 978-3-11-021339-3.

12. Latha, A.; Arivukarasi, M.; Keerthana, C.; Subashri, R.; Vishnu Priya, V. Paper and Pulp Industry Manufacturing and Treatment Processes-A Review. Int. J. Eng. Res. Technol. 2018, 6. [CrossRef]

13. Zerin, I.; Datta, E. A Review Article on Applications of Filter Cloth. Int. J. Cloth. Sci. 2018, 5, 1-6. [CrossRef]

14. Aaron, A.O.; Batchelor, N.W.; Garnier, G. Multi-Layer Filters: Adsorption and Filtration Mechanisms for Improved Separation. Front. Chem. 2018, 6, 417.

15. Rohrbach, K.; Li, Y.; Zhu, H.; Liu, Z.J.D.; Andreasen, J.; Hu, L. A cellulose based hydrophilic, oleophobic hydrated filter for water/oil separation. R. Soc. Chem. Chem. Commun. 2014, 50, 13296-13299. [CrossRef] [PubMed]

16. Brock, T.D. Membrane Filtration. A User's Guide and Reference Manual; Springer: Berlin/Heidelberg, Germany; New York, NY, USA, 1983; 381p, ISBN 3-540-12128-5.

17. Juneja, H.D.; Joshi, M.; Kanfade, J.P. Synthesis and Characterization of Metallic Gel Complexes Derived from Carboxymethyl Cellulose. J. Chem. 2013, 2013, 820328. [CrossRef]

18. Zhong, T.; Oporto, G.S.; Jaczynsky, J.; Tesfai, A.T.; Armstrong, J. Antimicrobial properties of the hybrid copper nanoparticles-carboxymethyl cellulose. Wood Fiber Sci. 2013, 45, 215-222. 
19. Hou, K.; Gerba, C.P.; Goyal, S.M.; Zerda, K.S. Capture of latex beads, bacteria, endotoxin, and viruses by charge-modified filters. Appl. Environ. Microbiol. 1980, 40, 892-896. [PubMed]

20. Sobsey, M.D.; Jones, B.L. Concentration of Poliovirus from Tap Water Using Positively Charged Microporous Filters. Appl. Environ. Micribiol. 1979, 588-595.

21. Chrowdhury, Z.; Summers, S.R.; Westerhoff, G.; Leto, B.J.; Norwack, K.; Corwin, C.; Passantino, L. Activated Carbon. Solution for Improving Water Quality; American Water Work Association: Washington, DC, USA, 2013; p. 353. ISBN 978-1-61300-202-5. (electronic).

22. Zhuravlev, I.; Zakutevsky, O.; Psareva, T.; Kanibolotsky, V.; Strelko, V.; Taffet, M.; Gallio, G. Uranium sorption on amorphous titanium and zirconium phosphates modified by $\mathrm{Al}^{3+}$ or $\mathrm{Fe}^{3+}$ ions. J. Radioanal. Nucl. Chem. 2002, 254, 85-89. [CrossRef]

23. Zhuravlev, I.; Kanibolotsky, V.; Strelko, V.; Bortun, A.; Bortun, L.; Khainakov, S.; Clearfield, A. Synthesis and Characterization of the Ion Exchange Properties of Spherically Granulated Sodium Aluminophosphatesilicate. Solvent Extr. Ion Exch. 1999, 17, 635-648. [CrossRef]

24. Zhuravlev, I.; Kanibolotsky, V.; Strelko, V.; Gallios, G.; Strelko, V., Jr. Novel High Porous Spherically Granulated Ferrophosphatesilicate Gels. Mater. Res. Bull. 2004, 39, 737-744. [CrossRef]

25. Zhuravlev, I.; Kanibolotsky, V.; Strelko, V.; Gallios, G. Novel Spherically Granulated Inorganic Ion Exchangers Based on Aluminophosphatesilicate and Ferrophosphatesilicate Gels. Sep. Sci. Technol. 2004, 39, 287-300. [CrossRef]

26. Srinivasan, M.; Ferraris, C.; White, T. Cadmium and lead ion capture with three dimensionally ordered macroporous hydroxyapatite. Environ. Sci. Technol. 2006, 40, 7054-7059. [CrossRef] [PubMed]

27. Elliott, J.C. Structure and Chemistry of the Apatites and Other Calcium Orthophosphates; Elsevier: Amsterdam, The Netherlands; London, UK; New York, NY, USA; Tokyo, Japan, 1994; p. 401, e-book; ISBN1 9781483290317. Hardcover; ISBN2 9780444815828.

(C) 2019 by the author. Licensee MDPI, Basel, Switzerland. This article is an open access article distributed under the terms and conditions of the Creative Commons Attribution (CC BY) license (http:/ / creativecommons.org/licenses/by/4.0/). 